
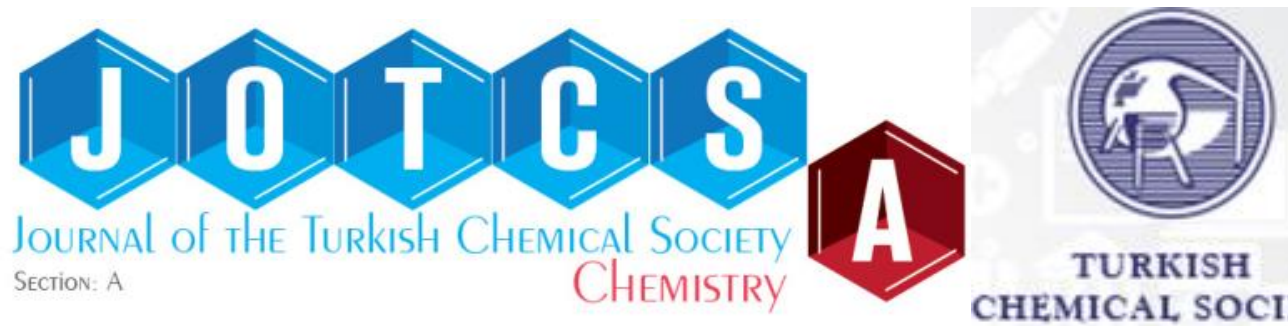

TURKISH

CHEMICAL SOCIETY

\title{
Synthesis and Characterization of A Novel Thermally Stable Schiff Base Oligomer: Investigation of Conductivity Properties
}

\author{
Nuray Yılmaz Baran* \\ Aksaray University, Technical Vocational School, Department of Chemistry Technology, 68100, \\ Aksaray, TURKEY
}

\begin{abstract}
This paper presents the design of a novel Schiff base, 2,2'-\{[1,2-di(pyridin-2yl)ethane-1,2-diylidene]bis(azanylylidene)\}diphenol (2,2'-DBD), and its oligophenol, Oligo(2,2'-\{[1,2-di(pyridin-2-yl)ethane-1,2-diylidene]bis(azanylylidene)\}diphenol) O(2,2'-DBD), synthesized with $\mathrm{NaOCl}$ and $\mathrm{O}_{2}$ oxidants by oxidative polycondensation reaction in aqueous alkaline media. The effects of oxidant type, polymerization temperature, and time on oligomer yield were determined. Characterization of the structures of the synthesized (2,2'-DBD) and $\mathrm{O}\left(2,2^{\prime}\right.$-DBD $)$ were done by UV-Vis, FTIR and ${ }^{1} \mathrm{HNMR}$ techniques. Also, thermal degradations of the monomer and oligomer were investigated TG-DTG analysis and it was determined that the oligomer thermally stable up to $1200^{\circ} \mathrm{C}$. Additionally, electrical conductivity of the oligomer was improved by doping with iodine at $20^{\circ} \mathrm{C}$ and the conductivity of the oligomer reached to $9 \times 10^{-4}$ $\mathrm{S} / \mathrm{cm}$ by increasing $10^{7}$ at the end of the $48 \mathrm{~h}$ doping time fold according to its undoped form.
\end{abstract}

Keywords: Conductivity, oxidative polycondensation, oligophenols, Schiff base polymers.

Submitted: November 22, 2017. Accepted: March 272018.

Cite this: .Yılmaz Baran N. Synthesis and Characterization of A Novel Thermally Stable Schiff Base Oligomer: Investigation of Conductivity Properties. JOTCSA. 2018;5(2):607-20.

DOI: http://dx.doi.org/10.18596/jotcsa.351460.

*Corresponding author. E-mail: nybaran@aksaray.edu.tr. Tel.:+90 382 2882028; Fax: +90 3822882125. 
Yılmaz Baran N. JOTCSA. 2018; 5(2): 607-620.

\section{INTRODUCTION}

Schiff base polymers, also known as polyazomethines, have drawn attention of researchers to design thermally resistant (1) and semiconductive (2) materials. They are promising materials for several applications such as photorefractive holographic materials (PRHMs) (3), solar cells (4) (SCs), organic light emitting diodes (OLEDs) (5), and organic field effect transistors (OFETs) (6).

Researchers have enhanced superior properties of the Schiff base polymers by adding different functional groups to their structures (7-11). One of these polymers are Schiff base polymers containing phenol groups. These polymers have excellent properties such as high thermal stability (12), bonding ability to metals (13), electrochemical $(14,15)$, antimicrobial $(11,16)$, semiconductive $(11,15)$, and superior optical (14) properties. Although several methods have been used $(17,18)$ to synthesize Schiff base polymers containing phenol groups, oxidative polycondensation method have been frequently preferred due to its superior advantages such as cheapness of the used oxidants $\left(\mathrm{NaOCl}, \mathrm{H}_{2} \mathrm{O}_{2}, \mathrm{O}_{2}\right)$, to synthesize polymers with high solubility, moderate reaction conditions and release of eco-friendly by products $\left(\mathrm{NaCl}\right.$ and $\left.\mathrm{H}_{2} \mathrm{O}\right)(12,19)$.

In this study, a novel Schiff base oligomer, $\mathrm{O}\left(2,2^{\prime}-\mathrm{DBD}\right)$, was produced with $\mathrm{NaOCl}$, and $\mathrm{O}_{2}$ oxidants by oxidative polycondensation of 2,2'-DBD monomer in an aqueous alkaline media. The effects of oxidant types, polymerization temperature, and time on oligomer yield were investigated. UV-Vis, FTIR, ${ }^{1} \mathrm{H}-\mathrm{NMR}$ techniques were used for verifying of structures of 2,2'-DBD and $\mathrm{O}\left(2,2^{\prime}-\mathrm{DBD}\right)$. Additionally, thermal degradations of monomer and oligomer were determined by TG-DTG. Also, the changing of electrical conductivity of $O\left(2,2^{\prime}-D B D\right)$ were monitored by doping with iodine at $20^{\circ} \mathrm{C}$ with increasing doping time.

\section{EXPERIMENTAL}

\section{Materials}

2-Aminophenol, 2,2'-pyridil, potassium hydroxide $(\mathrm{KOH})$, hydrochloric acid $(\mathrm{HCl}, 37 \%)$, iodine, acetone, dimethylformamide (DMF), dimethyl sulfoxide (DMSO), methanol, ethyl acetate, ethanol, $n$-methylpyrrolidone, 1,4-dioxane, $n$-heptane and tetrahydrofuran were purchased from Merck Chem. Co. (Germany). Also, sodium hypochlorite ( $\mathrm{NaOCl}, 15 \%$ aqu.) was supplied from Birpa Co. (Turkey).

\section{Method}

Synthesis of 2,2'-DBD

Production of 2,2'-DBD monomer was carried out by condensation of 2-aminophenol and 2,2'pyridil (Scheme 1). Solution of 2,2'-pyridil $(0,01 \mathrm{~mol}, 2.12 \mathrm{~g})$ prepared in $40 \mathrm{~mL}$ of methanol 
Yilmaz Baran N. JOTCSA. 2018; 5(2): 607-620.

was added on the solution of 2-aminophenol ( $0.02 \mathrm{~mol}, 2.18 \mathrm{~g})$ in $15 \mathrm{~mL}$ methanol. The prepared mixture was continuously stirred at $40^{\circ} \mathrm{C}$ for $24 \mathrm{~h}$. After the reaction was completed, ice watersalt mixture was added on the obtained brown solution

and the yellow product precipitated. Then it was filtered out and rinsed with cold methanol. The product was recrystallized from $\mathrm{n}$-heptane for purification. (Yield: $86 \%$; melting point: $147^{\circ} \mathrm{C}$.)

Synthesis of $O\left(2,2^{\prime}-D B D\right)$

$\mathrm{O}\left(2,2^{\prime}\right.$-DBD) was synthesized using $\mathrm{NaOCl}(15 \%)$, and air $\mathrm{O}_{2}$ oxidants by oxidative polycondensation reaction of 2,2'-DBD in aqueous alkaline media. Firstly, 2,2'-DBD (1 mmol, $0,394 \mathrm{~g})$ was dissolved in aqueous solution of $\mathrm{KOH}(10 \%, 1 \mathrm{mmol})$ under nitrogen atmosphere at the temperature which the polymerization reaction would be carried out. Then, $1 \mathrm{mmol} \mathrm{NaOCl}$ was added drop by drop. Nitrogen was passed during the reaction. When aerial $\mathrm{O}_{2}$ was used to be an oxidant, after the dissolution of monomer was completed, nitrogen gas was discontinued. At the end of the desired polymerization time, the cooled polymerization solution to room temperature was precipitated by neutralizing with $\mathrm{HCl}(37 \%)$. The product was filtered, washed with hot water and methanol, and then dried in oven.

Oligomer yield was determined using Equation 1:

$$
\text { Yield }(\%)=\frac{W_{\mathrm{p}}}{W_{\mathrm{m}}} \times 100
$$

Where $W_{p}$ and $W_{m}$ show the oligomer and initial monomer weights, respectively.

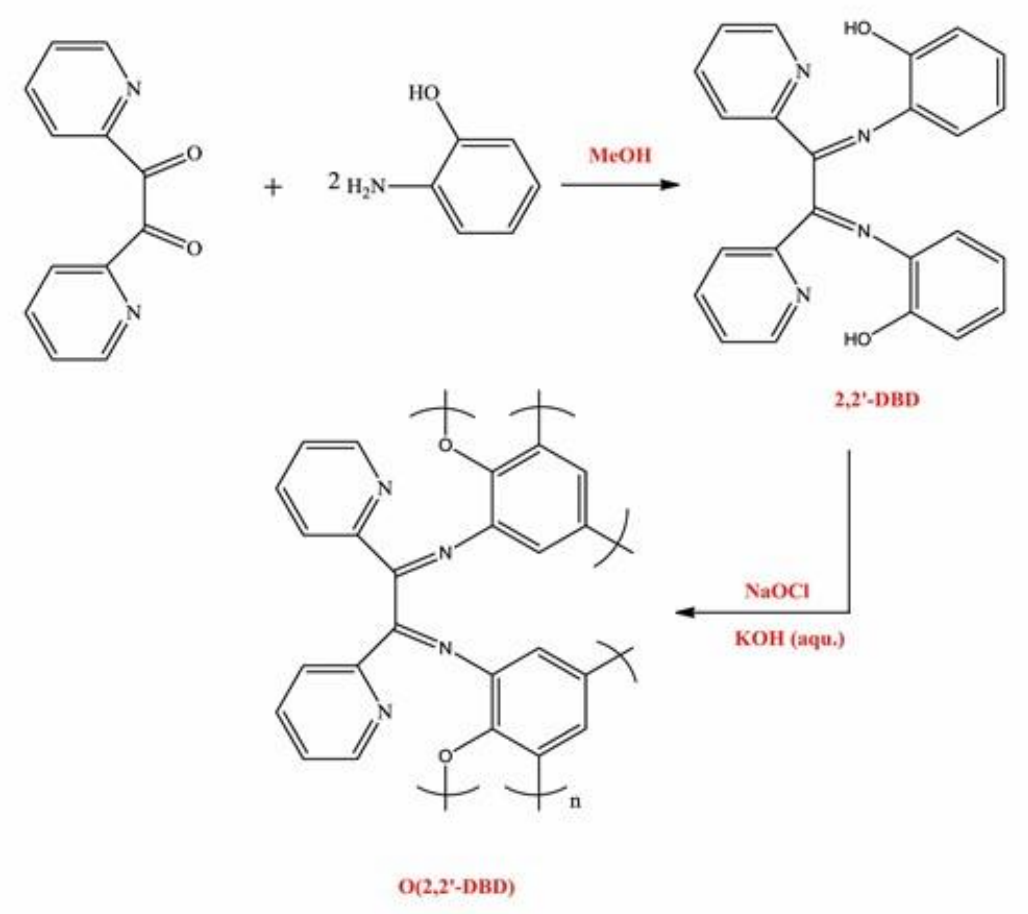

Scheme 1. Synthesis of $2,2^{\prime}-D B D$ and $O\left(2,2^{\prime}-D B D\right)$. 


\section{Characterization}

UV-Vis spectra of 2,2'-DBD and O(2,2'-DBD) were got in DMSO in a 260-700 nm wavelength range using Shimadzu UV-1700 PharmaSpec UV-Visible Spectrophotometer. FTIR spectra of the products were obtained by Perkin Elmer FTIR Spectrometer in the frequency range of 4000-650 $\mathrm{cm}^{-1}$. To clarify the molecular structures of the $2,2^{\prime}-\mathrm{DBD}$ and $\mathrm{O}\left(2,2^{\prime}-\mathrm{DBD}\right),{ }^{1} \mathrm{H}-\mathrm{NMR}$ spectra were acquired from their solutions in DMSO by Bruker Avance $500 \mathrm{MHz}$ NMR. Thermal degradations of the products were determined by TG/DTG techniques recorded in the temperature range of $30-1200{ }^{\circ} \mathrm{C}$ with a heating rate of $10^{\circ} \mathrm{C} / \mathrm{min}$ using EXSTAR S11 7300 thermal analyzer under nitrogen atmosphere with a platinum crucible. To determine molecular weight values of the oligomer, Shimadzu Prominence Gel Permeation Chromatography which was fitted out a Nucleogel GPC 103-5 VA300/7.7 column was employed (eluent: DMF, flow rate: $0.5 \mathrm{~mL} / \mathrm{min}$, temperature: $40^{\circ} \mathrm{C}$ ).

Surface resistivity values of the oligomer were measured from the prepared sample pellets 2 $\mathrm{mm}$ thick and $1.3 \mathrm{~cm}$ in diameter under a hydraulic pressure $\left(1687.2 \mathrm{~kg} / \mathrm{cm}^{2}\right)$ by two probe technique. The electrical conductivity values of the $\mathrm{O}\left(2,2^{\prime}-\mathrm{DBD}\right)$ were calculated using the measured surface resistivity values according to Equation 2:

$$
\sigma=\frac{l}{R a}
$$

Where $\sigma(\mathrm{S} / \mathrm{cm})$ corresponds the conductivity of the oligomer, $R\left(\mathrm{ohm} \mathrm{cm}^{-2}\right.$ ) is the monitored surface resistivity. $a\left(\mathrm{~cm}^{2}\right)$ and $I(\mathrm{~cm})$ are the area and thickness of the prepared sample pellet, respectively.

\section{Solubility test}

To determine qualitative solubility of 2,2'-DBD and $O\left(2,2^{\prime}\right.$-DBD $) 1 \mathrm{mg}$ sample was dissolved in $1 \mathrm{~mL}$ of solvent (Table 1 ). It was observed that 2,2'-DBD dissolved in all of the tested solvents at room temperature. However, $\mathrm{O}\left(2,2^{\prime}-\mathrm{DBD}\right)$ was only dissolved in DMF and DMSO. The solubility of the oligomer will facilitate the characterization and processability of the oligomer.

Table 1. The solubility of $2,2^{\prime}-D B D$ and $O\left(2,2^{\prime}-D B D\right)$ in several solvents.

\begin{tabular}{|c|c|c|c|c|c|c|c|c|c|c|}
\hline & 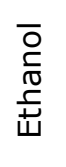 & $\begin{array}{l}\bar{O} \\
\frac{1}{0} \\
\frac{0}{1} \\
+\frac{1}{0} \\
\sum\end{array}$ & 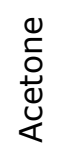 & 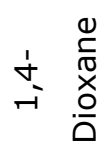 & $\sum_{\Delta}^{L}$ & $\begin{array}{l}0 \\
\sum_{0}^{n}\end{array}$ & $\sum_{z}^{n}$ & 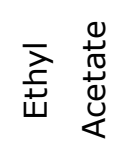 & 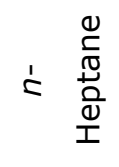 & 岌 \\
\hline \multicolumn{11}{|l|}{$2,2^{\prime}-\mathrm{DBD}$} \\
\hline & + & + & + & + & + & + & + & + & + & + \\
\hline $\mathrm{O}\left(2,2^{\prime}-\mathrm{DBD}\right)$ & - & - & - & - & + & + & - & - & - & - \\
\hline
\end{tabular}


Yilmaz Baran N. JOTCSA. 2018; 5(2): 607-620.

\section{RESULTS AND DISCUSSION}

\section{Effect of Synthesis Conditions on the Yield of $O\left(2,2^{\prime}-D B D\right)$}

\section{Oxidant type and concentration}

$\mathrm{O}\left(2,2^{\prime}\right.$-DBD) was synthesized in aqueous alkaline media with $\mathrm{NaOCl}$ and $\mathrm{O}_{2}$ (aerial) oxidants. Yields and molecular weight values of oligomers which obtained $80^{\circ} \mathrm{C}$ for $6 \mathrm{~h}$ (11) were determined. While yield and $\mathrm{M}_{\mathrm{w}}, \mathrm{Mn}_{\mathrm{n}}$ and PDI values of the oligomer synthesized with $\mathrm{NaOCl}$ oxidant were $76 \%$ and $5435,4216 \mathrm{~g} / \mathrm{mol}$ and 1.28 , the same values, which were obtained using air $\mathrm{O}_{2}$ as oxidant, were $8 \%$ and $1321,992 \mathrm{~g} / \mathrm{mol} 1.33$, respectively. Thus, since higher yield and molecular weight values were obtained with $\mathrm{NaOCl}$ oxidant, the next experiments were carried out using $\mathrm{NaOCl}(11,20,21)$. Also, $0.1 \mathrm{~mol} / \mathrm{L} \mathrm{NaOCl}$ concentration at which the highest polymer yields were obtained in the literature was used in the experiments.

\section{Polymerization temperature and time}

The effect of polymerization temperature and time on oligomer yield were investigated and the data were given in Figures 1 and 2, respectively.

As seen from Figure 1, the oligomer yield increased with increasing polymerization temperature $(11,12)$. Thus, the following experiments were performed at $90^{\circ} \mathrm{C}$ which the highest oligomer yield was obtained.

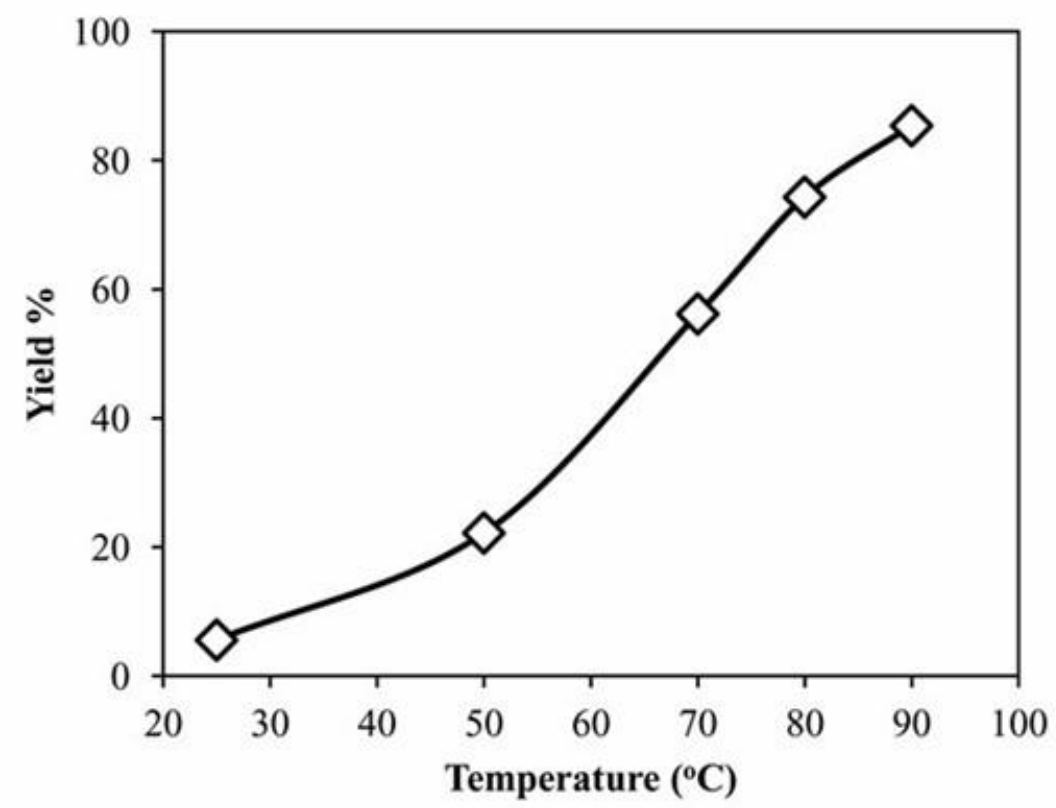

Figure 1. The effect of polymerization temperature on \% yield of $O\left(2,2^{\prime}-D B D\right)$ $\left(\left[2,2^{\prime}-\mathrm{DBD}\right]_{0}==[\mathrm{NaOCl}]_{0}=[\mathrm{KOH}]_{0}=0.1 \mathrm{~mol} / \mathrm{L}\right.$, polymerization time: $\left.6 \mathrm{~h}\right)$.

When Figure 2, showing the change of the oligomer yield with polymerization time, was examined, it was seen that the yield increased with increasing time up to $4 \mathrm{~h}$. A significant 
increase in yield was not seen after $4 \mathrm{~h}$. Also, the highest oligomer yield ( $85.4 \%$ ) was obtained at the end of $6 \mathrm{~h}$.

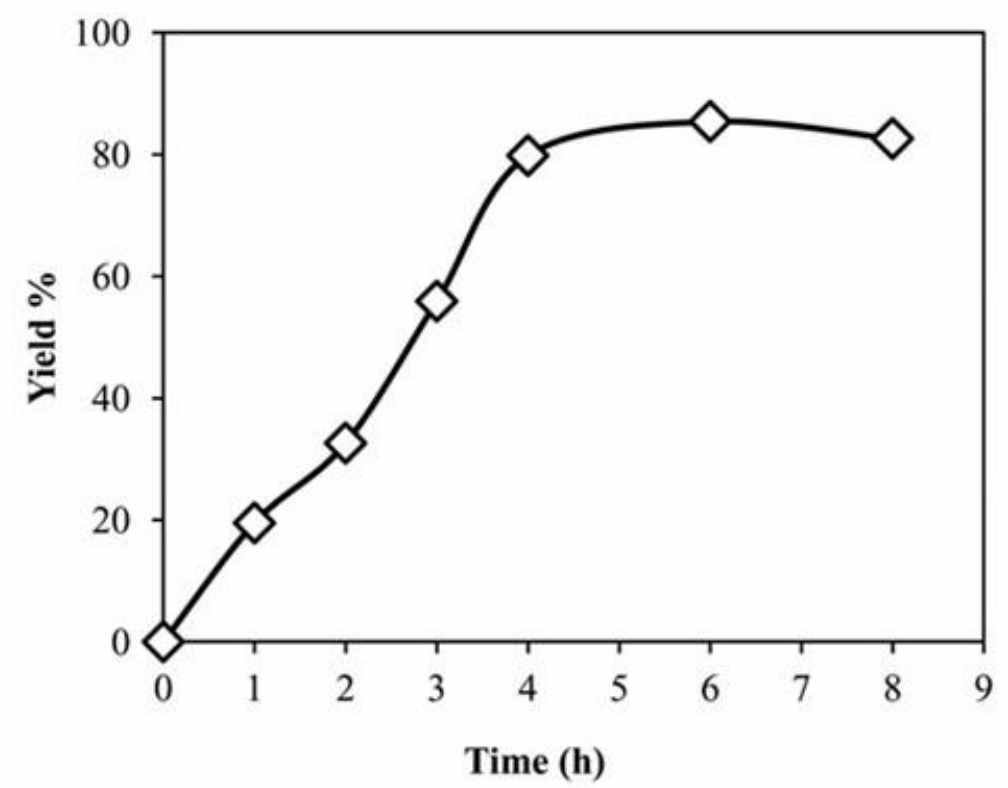

Figure 2. The effect of polymerization time on $\%$ yield of $O\left(2,2^{\prime}-D B D\right)$ $\left(\left(\left[2,2^{\prime}-\mathrm{DBD}\right]_{0}==[\mathrm{NaOCl}]_{0}=[\mathrm{KOH}]_{0}=0.1\right.\right.$, polymerization temperature: $\left.90^{\circ} \mathrm{C}\right)$.

\section{Structures of 2,2'-DBD and $O\left(2,2^{\prime}-D B D\right)$}

\section{UV-Vis Spectra}

UV-Vis spectra of 2,2'-DBD and $\mathrm{O}\left(2,2^{\prime}\right.$-DBD $)$ acquired from their solutions in DMSO in the range of 250-700 nm wavelength are presented in Figure 3. While it is seen a sharp band at $302 \mathrm{~nm}$ wavelength and a shoulder at $341 \mathrm{~nm}$ in the spectrum of 2,2'-DBD, the same bands are observed at wavelengths of 270 and $305 \mathrm{~nm}$ as shoulders in the spectrum of oligomer. These bands can be ascribed to $\Pi-\Pi^{*}$ transitions of $-\mathrm{C}=\mathrm{C}-, \Pi^{*} \Pi^{*}$ transitions of the imine functional groups and the $\mathrm{n}-\Pi^{*}$ transitions of $\mathrm{OH}$ functional groups, respectively. When the spectra of monomer and oligomer were compared to each other, it was determined that the $O\left(2,2^{\prime}\right.$-DBD $)$ spectrum broadened to $700 \mathrm{~nm}$ while the spectrum of 2,2'-DBD finished at $500 \mathrm{~nm}$, and the bands of oligomer broadened and shifted to blue wavelengths. These changes originate from increasing of conjugation during polymerization and verify that polymerization was achieved $(11,13,21$, 22). 


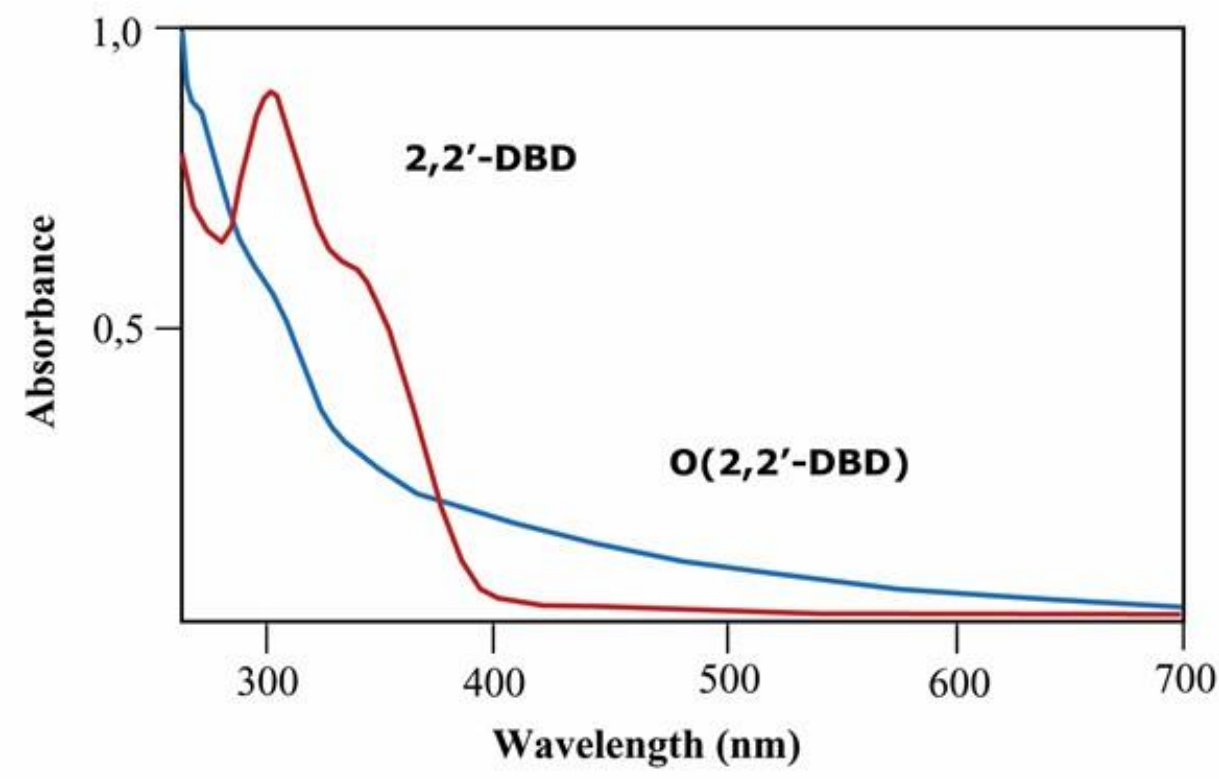

Figure 3. UV-Vis spectra of $2,2^{\prime}-D B D$ and $O\left(2,2^{\prime}-D B D\right)$.

\section{FTIR Spectra}

FTIR spectra recorded to support the structures of $2,2^{\prime}-D B D$ and $O\left(2,2^{\prime}-D B D\right)$ and emphasize the changes in the structure after polymerization are given in Figure 4.

In the spectrum of 2,2'-DBD, while the peak seen at $3056 \mathrm{~cm}^{-1}$ is arisen from phenolic $\mathrm{OH}$ groups, the same peak is determined at $3364 \mathrm{~cm}^{-1}$ in the $\mathrm{O}\left(2,2^{\prime}-\mathrm{DBD}\right)$ spectrum. While the $-\mathrm{C}=\mathrm{N}$ vibration, which is characteristic for Schiff bases, is appeared to be sharp peak at $1620 \mathrm{~cm}^{-1}$ in the monomer spectrum, in the oligomer spectrum this vibration shifted to $1606 \mathrm{~cm}^{-1}$. The presence of the $-\mathrm{C}=\mathrm{N}$ - peak in the oligomer spectrum also indicates that the imine groups characteristic for polyazomethines are preserved without decomposition during polymerization (11). Additionally, the peaks at 1587, 1468, $1435 \mathrm{~cm}^{-1}$ in the monomer spectrum and at 1582 and $1562 \mathrm{~cm}^{-1}$ in the oligomer spectrum are due to $-\mathrm{C}=\mathrm{C}-$ vibrations. While the peaks belonging to -C-O- and C-N stretching vibrations are seen at 1235 and $1137 \mathrm{~cm}^{-1}$ for monomer, these same peaks are recorded at 1232 and $1098 \mathrm{~cm}^{-1}$ for oligomer, respectively. When the FTIR spectra of monomer and oligomer are compared to each other, the changes (i) broadening of the peaks, (ii) decrease in the peak number and (iii) shifting in the characteristic $-\mathrm{C}=\mathrm{N}-$ vibration to lower wavenumber are seen in the oligomer spectrum. All of these changes are originated from increasing in conjugation length and support that the polymeric structure was achieved $(11,13$, $21,22)$. 


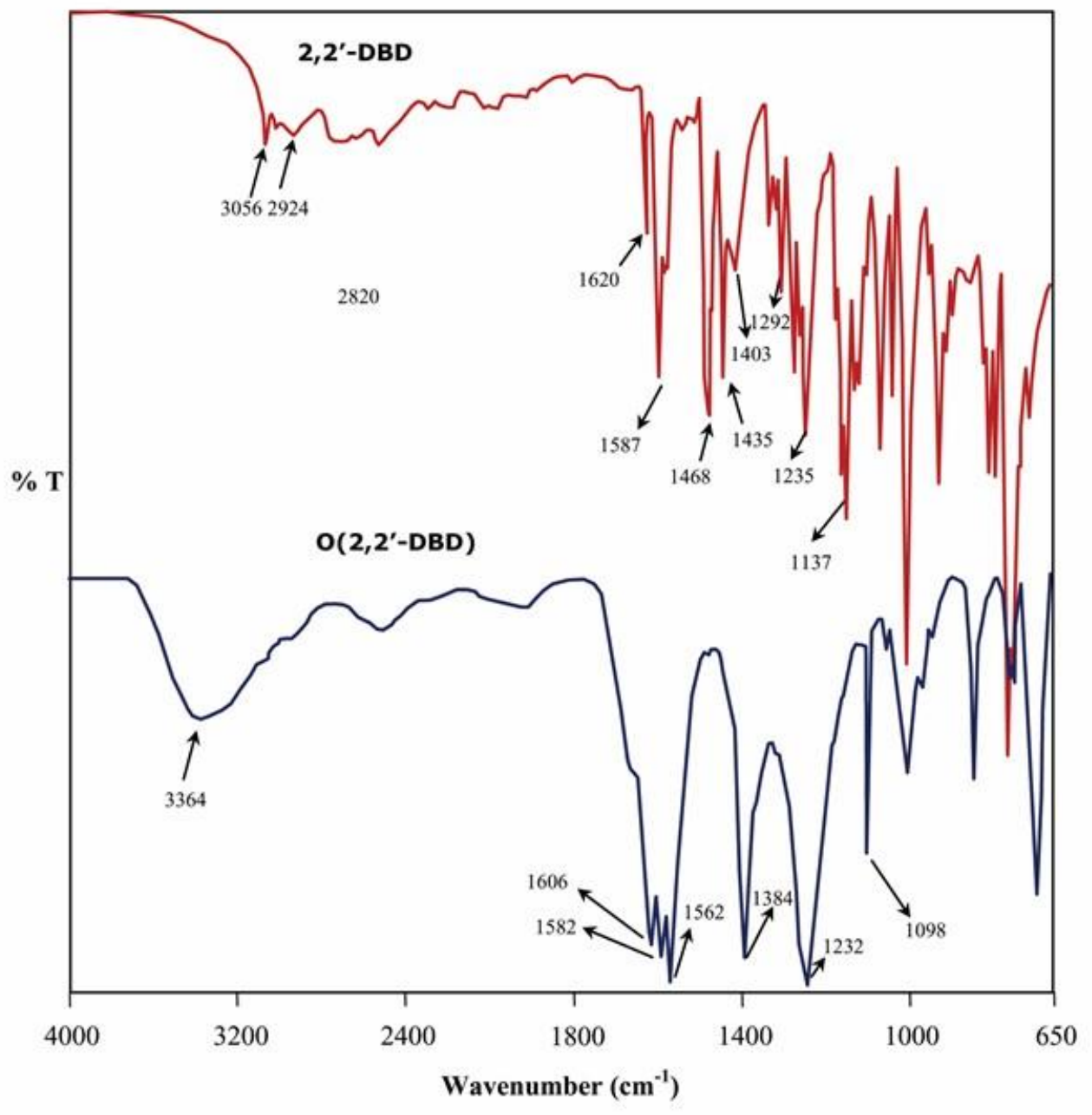

Figure 4. FTIR spectra of $2,2^{\prime}-D B D$ and $O\left(2,2^{\prime}-D B D\right)$.

\section{${ }^{1} H-N M R$ Spectra}

To prove that the synthesis of $2,2^{\prime}$-DBD and $\mathrm{O}\left(2,2^{\prime}\right.$-DBD $)$ was successfully performed, ${ }^{1} \mathrm{H}-\mathrm{NMR}$ spectra of the samples were recorded and they are presented in Figure 5 and 6, respectively. In the ${ }^{1} \mathrm{H}$-NMR spectrum of Schiff base monomer, the signal of protons $-\mathrm{OH}$ functional groups is seen at $10.55(\mathrm{~s}, 2 \mathrm{H})$. The other signals indicating the aromatic structure of 2,2'-DBD were determined at $\delta=7.90\left(\mathrm{~d}, 2 \mathrm{H}, \mathrm{Ar}-\mathrm{H}_{\mathrm{a}}\right) ; 7.82\left(\mathrm{t}, 2 \mathrm{H}, \mathrm{Ar}-\mathrm{H}_{\mathrm{b}}\right) ; 7.78(\mathrm{t}, 2 \mathrm{H}, \mathrm{Ar}-\mathrm{Hc}) ; 7.57(\mathrm{~d}, 2 \mathrm{H}, \operatorname{Ar}-$ $\left.\mathrm{H}_{d}\right) ; 7.27\left(\mathrm{t}, 2 \mathrm{H}, \mathrm{Ar}-\mathrm{H}_{\mathrm{f}}\right) ; 7.21\left(\mathrm{~d}, 2 \mathrm{H}, \mathrm{Ar}-\mathrm{H}_{\mathrm{h}}\right) ; 7.09\left(\mathrm{~d}, 2 \mathrm{H}, \mathrm{Ar}-\mathrm{H}_{\mathrm{e}}\right) ; 6.96\left(\mathrm{t}, 2 \mathrm{H}, \mathrm{Ar}-\mathrm{H}_{\mathrm{g}}\right)$ ppm. Also the signals confirming the aromatic structure of $\mathrm{O}\left(2,2^{\prime}-\mathrm{DBD}\right)$ were recorded at $\delta=8.53(\mathrm{~s}, 2 \mathrm{H}$, Ar- $\left.\mathrm{H}_{\mathrm{f}}\right) ; 8.40\left(\mathrm{~s}, 2 \mathrm{H}, \mathrm{Ar}-\mathrm{H}_{\mathrm{e}}\right) 7.80\left(\mathrm{~d}, 2 \mathrm{H}, \mathrm{Ar}-\mathrm{H}_{\mathrm{a}}\right) ; 7.78\left(\mathrm{t}, 2 \mathrm{H}, \mathrm{Ar}-\mathrm{H}_{\mathrm{b}}\right) ; 7.66\left(\mathrm{t}, 2 \mathrm{H}, \mathrm{Ar}-\mathrm{H}_{\mathrm{c}}\right) ; 7.20(\mathrm{~d}$, $\left.2 \mathrm{H}, \mathrm{Ar}-\mathrm{H}_{\mathrm{d}}\right) \mathrm{ppm}$. When the ${ }^{1} \mathrm{H}-\mathrm{NMR}$ spectrum of oligomer is compared to monomer spectrum, (I) absence of the signals of $\mathrm{H}_{\mathrm{e}}$ (dublet) and $\mathrm{H}_{\mathrm{g}}$ (triplet) protons of monomer, in the polymer spectrum, (II) while $\mathrm{H}_{\mathrm{f}}$ and $\mathrm{H}_{\mathrm{h}}$ protons of monomer seen as triplet and dublet, respectively in the monomer spectrum, observation of the same protons as singlets in the polymer spectrum, emphasizing that the oligomerization continues from the $\mathrm{C}-\mathrm{C}$ couplings which occur on the ortho and para positions of the $\mathrm{OH}$ groups. Moreover, absence of the signal of $\mathrm{OH}$ groups in the polymer 
spectrum states that the oligomerization also progresses from $\mathrm{C}-\mathrm{O}-\mathrm{C}$ couplings which form from $\mathrm{OH}$ groups in addition to $\mathrm{C}-\mathrm{C}$ couplings $(11,15,21)$.

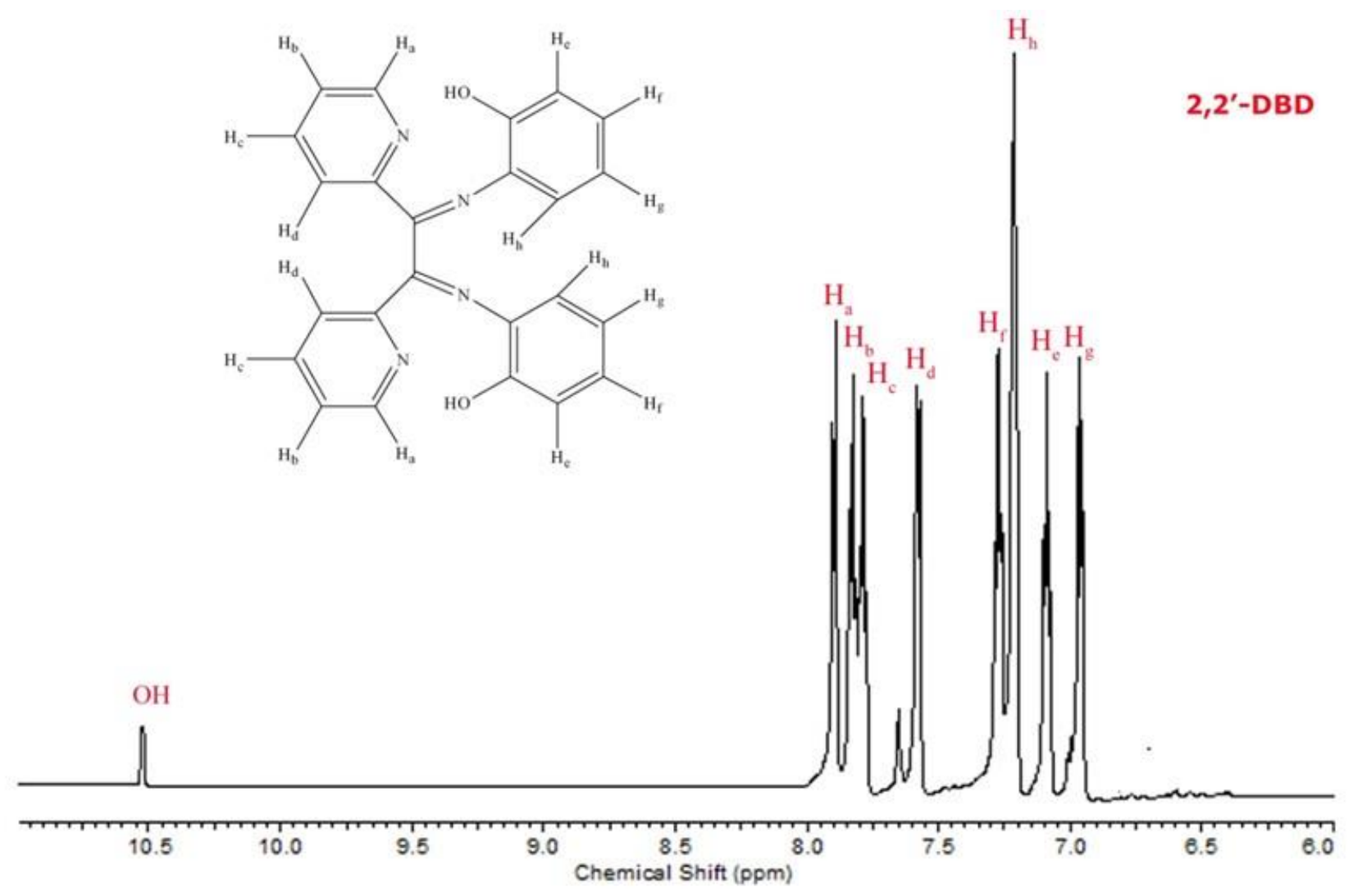

Figure 5. ${ }^{1} \mathrm{H}$ NMR spectrum of $2,2^{\prime}-\mathrm{DBD}$.

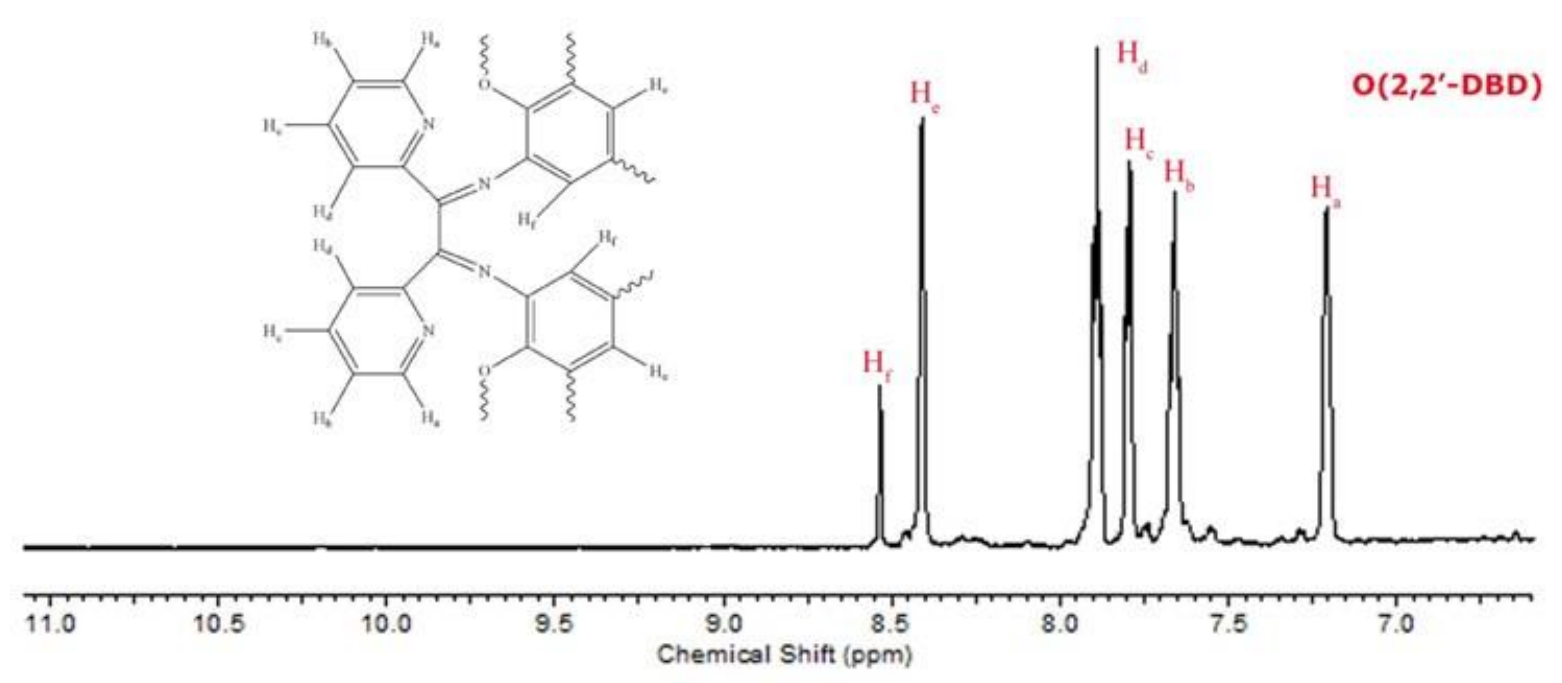

Figure 6. ${ }^{1} \mathrm{H}$ NMR spectrum of $\mathrm{O}\left(2,2^{\prime}-\mathrm{DBD}\right)$. 
Yılmaz Baran N. JOTCSA. 2018; 5(2): 607-620.

\section{Thermal Degradation Process of O(2,2'-DBD)}

To determine the thermal stability of $2,2^{\prime}-D B D$ and $O\left(2,2^{\prime}-D B D\right)$, their TG and DTG curves were acquired up to 600 and $1200^{\circ} \mathrm{C}$, respectively (Figure 7). It was determined from TG curve of $2,2^{\prime}$-DBD that 2,2'-DBD decomposed in two steps which are in the temperature range of 166 $282{ }^{\circ} \mathrm{C}$ and $282-560{ }^{\circ} \mathrm{C}$. The monomer which started to degrade at $166^{\circ} \mathrm{C}$ finished the process at $78.25 \%$ up to $282{ }^{\circ} \mathrm{C}$. Also the weight loss in the second degradation step was $21.75 \%$ in the temperature range of $282-560{ }^{\circ} \mathrm{C}$. The maximum degradation temperature $\left(T_{\max }\right)$ were determined from DTG curve as $243^{\circ} \mathrm{C}$.

From the TG curve, which was recorded up to $1200^{\circ} \mathrm{C}$, belonging to $\mathrm{O}\left(2,2^{\prime}-\mathrm{DBD}\right)$, it was seen that the oligomer degraded in three steps. Firstly, the weight loss of $4.25 \%$ in the temperature range of $30-180^{\circ} \mathrm{C}$ can be ascribed to removal of water of crystallization (23). The other weight losses of the oligomer were determined as $8.5 \%$ in the temperature range of $180-339{ }^{\circ} \mathrm{C}$ for the first step, $20.25 \%$ in the temperature range of $339-555^{\circ} \mathrm{C}$ for the second step and $67.0 \%$ in the temperature range of $555-1200{ }^{\circ} \mathrm{C}$ for the third step. The maximum degradation temperatures ( $T_{\max }$ ) found from DTG curve corresponded to $136^{\circ} \mathrm{C}, 264^{\circ} \mathrm{C}, 442{ }^{\circ} \mathrm{C}$, and 867 ${ }^{\circ} \mathrm{C}$ for each degradation steps, respectively.

When the thermal degradations of the monomer and oligomer were compared to each other, while the temperatures at which the $30 \%$ weight loss formed were $234^{\circ} \mathrm{C}$ and $464{ }^{\circ} \mathrm{C}$, these temperatures for $50 \%$ weight loss were $251{ }^{\circ} \mathrm{C}$ and $784{ }^{\circ} \mathrm{C}$ for monomer and oligomer, respectively. Moreover, while the monomer completely decomposed up to $560{ }^{\circ} \mathrm{C}$ without any carbon residue, the oligomer completely degraded up to $1200{ }^{\circ} \mathrm{C}$ without any carbon residue. These data verify that the thermal stability of oligomer is much higher than its monomer. The case is also due to the increasing conjugation of the oligomer according to monomer $(11,13$, 21). 

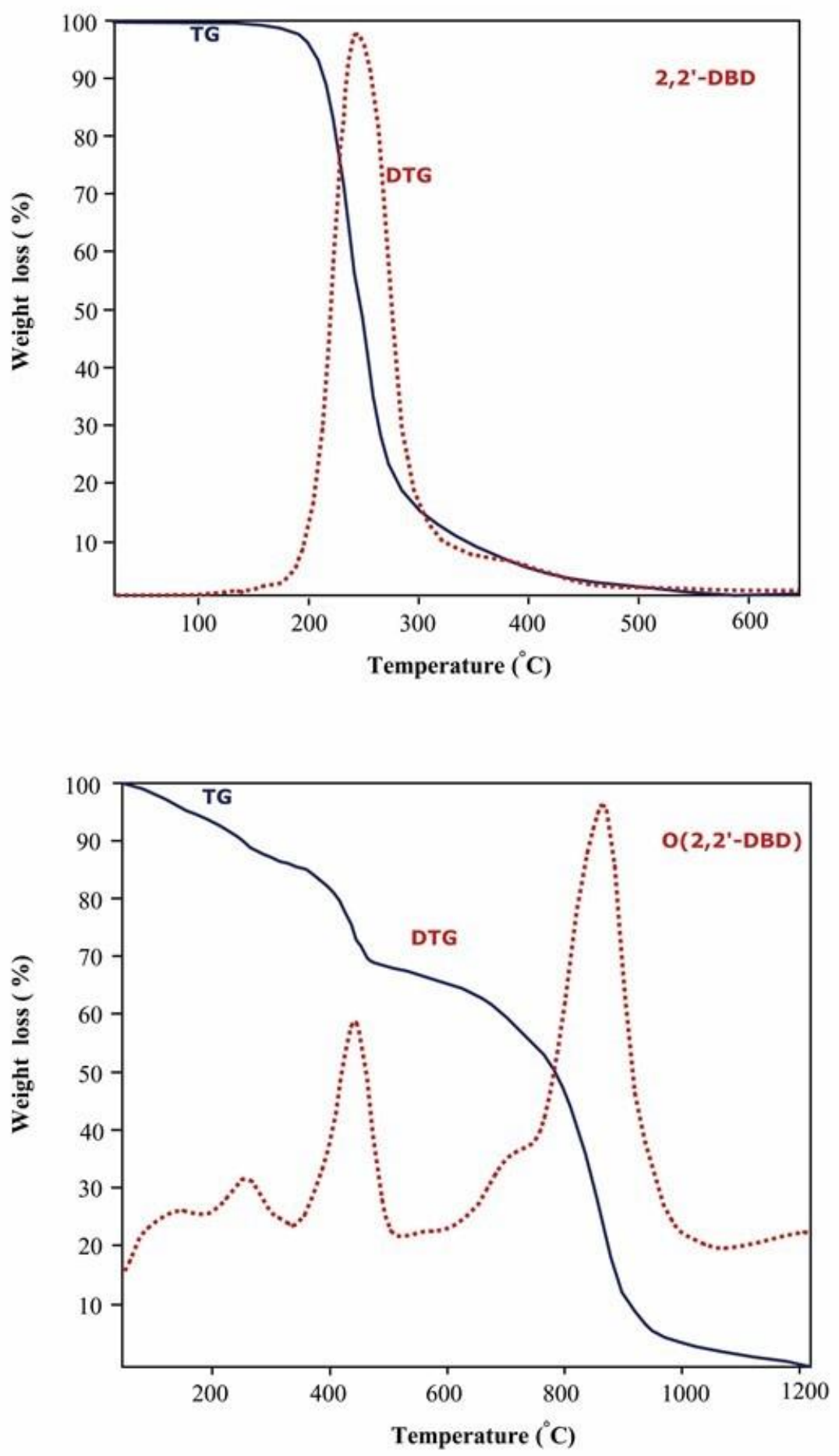

Figure 7. TG and DTG curves of $2,2^{\prime}-\mathrm{DBD}$ and $\mathrm{O}\left(2,2^{\prime}-\mathrm{DBD}\right)$.

\section{Doping with Iodine}

The effects of doping time were monitored on conductivity of oligomer which was doped with iodine vapor at $20^{\circ} \mathrm{C}$ up to $120 \mathrm{~h}$ and the obtained data are presented in Figure 8 . The initial conductivity value of the oligomer was measured as $6.5 \times 10^{-11} \mathrm{~S} / \mathrm{cm}$ before doping. By starting of doping, the conductivity value of the oligomer increased fastly and the conductivity value was measured as $8 \times 10^{-5} \mathrm{~S} / \mathrm{cm}$ by increasing $10^{6}$ fold after doping $1 \mathrm{~h}$. The increase of the conductivity 
Yilmaz Baran N. JOTCSA. 2018; 5(2): 607-620.

RESEARCH ARTICLE

value continued to $48 \mathrm{~h}$ with increasing doping time and at the end of the $48 \mathrm{~h}$ doping time, the values was reached to $9 \times 10^{-4} \mathrm{~S} / \mathrm{cm}$ by increasing $10^{7}$ fold according to initial conductivity value. After $48 \mathrm{~h}$ doping time, it was not observed a significant increase in the conductivity.

This doping process occurring between iodine and the Schiff base oligomer can be explained by the coordination between iodine molecules and the highly electronegative $\mathrm{N}$ atoms of the oligomer $(24,25)$.

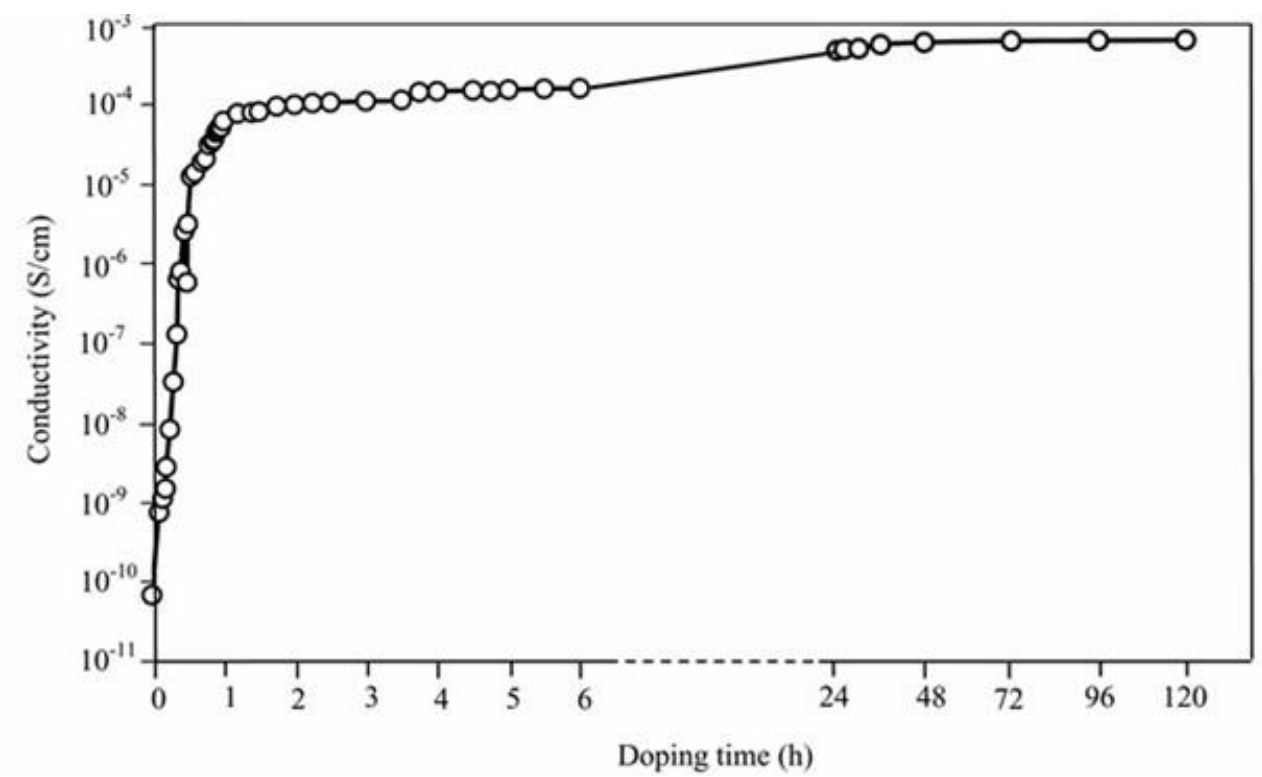

Figure 8. The effect of doping time with iodine on conductivity of $\mathrm{O}\left(2,2^{\prime}-\mathrm{DBD}\right)$ at $25{ }^{\circ} \mathrm{C}$.

\section{CONCLUSIONS}

Within the scope of this study, synthesis of $O\left(2,2^{\prime}-D B D\right)$ was achieved by oxidative polycondensation reaction of 2,2'-DBD in an aqueous alkaline media using $\mathrm{NaOCl}$ and $\mathrm{O}_{2}$ oxidants. To be soluble oligomer in DMF, DMSO, which were the most widely used organic solvents, enables us to investigate different analytical, environmental usages and its properties such as fluorescence and phosphorescence, catalysis and antimicrobial activity. From the thermal analysis results, it was determined that the oligomer is thermally stable up to $1200^{\circ} \mathrm{C}$ and it facilitates that the oligomer may be used in materials which requires high thermal resistance. The studies carried out to increase the conductivity of the oligomer showed that the conductivity value of the oligomer increased $10^{7}$ fold according to initial conductivity value and it was measured $9 \times 10^{-4} \mathrm{~S} / \mathrm{cm}$ at $20^{\circ} \mathrm{C}$ after doping $48 \mathrm{~h}$. Thus, it can be said that the oligomer could be used in applications which require semiconductive properties. 


\section{REFERENCES}

1. Spiliopoulos IK, Mikroyannidis JA. Soluble, Rigid-Rod Polyamide, Polyimides, and Polyazomethine with Phenyl Pendent Groups Derived from 4,4"-Diamino-3,5,3",5"-tetraphenyl-p-terphenyl. Macromolecules. 1996;29(16):5313-9.

2. Aly KI, Khalaf AA. New polymer syntheses. IX. Synthesis and properties of new conducting polyazomethine polymers containing main chain cycloalkanone and pyridine moieties. Journal of Applied Polymer Science. 2000;77(6):1218-29.

3. Jae-Wook K, Jang-Joo K, Jinkyu K, Xiangdan L, Myong-Hoon L. Low-loss and thermally stable TEmode selective polymer waveguide using photosensitive fluorinated polyimide. IEEE Photonics Technology Letters. 2002;14(9):1297-9.

4. Iwan A, Boharewicz B, Tazbir I, Malinowski M, Filapek M, Kłąb T, et al. New environmentally friendly polyazomethines with thiophene rings for polymer solar cells. Solar Energy. 2015;117:246-59.

5. Niu H, Huang Y, Bai X, Li X, Zhang G. Study on crystallization, thermal stability and hole transport properties of conjugated polyazomethine materials containing 4,4'-bisamine-triphenylamine. Materials Chemistry and Physics. 2004;86(1):33-7.

6. Iwan A, Palewicz M, Chuchmala A, Sikora A, Gorecki L, Sek D. Opto(electrical) properties of triphenylamine-based polyazomethine and its blend with 6,6 -phenyl C-61 butyric acid methyl ester. High Perform Polym. 2013;25(7):832-42.

7. Kamacı M, Kaya İ. 2,4-Diamino-6-Hydroxypyrimidine Based Poly(azomethine-Urethane): Synthesis and Application as a Fluorescent Probe for Detection of Cu2+ in Aqueous Solution. Journal of Fluorescence. 2015;25(5):1339-49.

8. Marin L, Cozan V, Bruma M, Grigoras VC. Synthesis and thermal behaviour of new poly(azomethine-ether). European Polymer Journal. 2006;42(5):1173-82.

9. Sęk D. Liquid crystalline properties of new poly(azomethine esters). European Polymer Journal. $1984 ; 20(9): 923-6$.

10. Cozan V, Butuc E, Stoleriu A, Rusa M, Rusu M, Ni Y, et al. Poly(Azomethine Sulfones) with Thermotropic Liquid Crystalline Behavior. Journal of Macromolecular Science, Part A. 1995;32(7):124362.

11. Yılmaz Baran N, Demir HÖ, Kostekçi S, Sacak M. Poly-2-[(4-methylbenzylidene)amino]phenol: Investigation of thermal degradation and antimicrobial properties. Journal of Applied Polymer Science. $2015 ; 132(14): n / a-n / a$.

12. Demir HÖ. Ketimine substituted polyphenol: Synthesis, characterization and investigation of its thermal and electrochemical properties. Journal of Applied Polymer Science. 2013;127(6):5037-44.

13. Demetgül C, Delikanlı A, Sarıbıyık OY, Karakaplan M, Serin S. Schiff Base Polymers Obtained by Oxidative Polycondensation and Their $\mathrm{Co}(\mathrm{II}), \mathrm{Mn}(\mathrm{II})$ and $\mathrm{Ru}(\mathrm{III})$ Complexes: Synthesis, Characterization and Catalytic Activity in Epoxidation of Styrene. Designed Monomers and Polymers. 2012;15(1):75-91.

14. Kaya İ, Yıldırım M, Avcı A. Synthesis and characterization of fluorescent polyphenol species derived from methyl substituted aminopyridine based Schiff bases: The effect of substituent position on optical, electrical, electrochemical, and fluorescence properties. Synthetic Metals. 2010;160(9-10):91120.

15. Yıldırım M, Kaya İ. Synthesis and characterizations of poly(ether)/poly(phenol)s including azomethine coupled benzothiazole side chains: the effect of reaction conditions on the structure, optical, electrochemical, electrical and thermal properties. Polymer Bulletin. 2014;71(12):3067-84.

16. Kaya, Emdi D, Saçak M. Synthesis, Characterization and Antimicrobial Properties of Oligomer and Monomer/Oligomer-Metal Complexes of 2-[(Pyridine-3-yl-methylene)amino]phenol. J Inorg Organomet Polym. 2009;19(3):286-97. DOI: 10.1007/s10904-009-9270-z. 
Yılmaz Baran N. JOTCSA. 2018; 5(2): 607-620.

17. Kaya İ, Aydın A. A new approach for synthesis of electroactive phenol based polymer: 4-(2,5$\mathrm{Di}($ thiophen-2-yl)-1H-pyrrol-1-yl)phenol and its oxidative polymer. Progress in Organic Coatings. 2012;73(2):239-49.

18. Eker B, Zagorevski D, Zhu G, Linhardt RJ, Dordick JS. Enzymatic polymerization of phenols in room-temperature ionic liquids. Journal of Molecular Catalysis B: Enzymatic. 2009;59(1):177-84.

19. Mart H. Oxidative polycondensation reaction. Designed Monomers and Polymers. 2006;9(6):55188.

20. Yılmaz Baran N, Saçak M. Synthesis, characterization and molecular weight monitoring of a novel Schiff base polymer containing phenol group: Thermal stability, conductivity and antimicrobial properties. Journal of Molecular Structure. 2017;1146(Supplement C):104-12.

21. Yılmaz Baran N, Karakışla M, Demir HÖ, Saçak M. Synthesis, characterization, conductivity and antimicrobial study of a novel thermally stable polyphenol containing azomethine group. Journal of Molecular Structure. 2016;1123:153-61.

22. Özbülbül A, Mart H, Tunçel M, Serin S. A new soluble Schiff base polymer with a double azomethine group synthesized by oxidative polycondensation. Designed Monomers and Polymers. 2006;9(2):169-79.

23. Cazacu M, Marcu M, Vlad A, Rusu GI, Avadanei M. Chelate polymers. VI. New copolymers of the some siloxane containing bis(2,4-dihydroxybenzaldehyd-imine)Me2+ with bis(p-

carboxyphenyl)diphenylsilane. Journal of Organometallic Chemistry. 2004;689(19):3005-11.

24. Diaz FR, Moreno J, Tagle LH, East GA, Radic D. Synthesis, characterization and electrical properties of polyimines derived from selenophene. Synthetic Metals. 1999;100(2):187-93.

25. Kaya I, Bilici A, Sacak M. New conjugated azomethine oligomers obtained from bis(hydroxyphenyl)methylenediamine via oxidative polycondensation and their complexes with metals. Synthetic Metals. 2009;159(14):1414-21. 